\title{
Data protection gone too far: questionnaire survey of patients' and visitors' views about having their names displayed in hospital
}

\author{
Ravindra Gudena, Stanley Luwemba, Amy Williams, Lloyd R Jenkinson
}

In the past few months, patients' identification name boards have been intentionally removed from hospital wards. The name board is a plan of the ward with the name, location, and consultant in charge of each patient clearly displayed in front of the central nursing station. This ensures that all members of staff can quickly and correctly locate patients. Patients are also identified by a name card above their beds that shows their name and their consultant. Managers feel that these do not comply with the Data Protection Act 1998 and are removing them. ${ }^{12}$

Since these changes have been made, we have misplaced patients as no one was aware that they were still in hospital. We felt this was an unacceptable and dangerous practice and did a survey to find out how patients and visitors feel about having patients' names displayed on name boards and name cards on the ward.

\section{Participants, methods, and results}

We gave separate multiple choice questionnaires to a random sample of patients and their relatives in three surgical and two orthopaedic wards in a rural district general hospital in Wales, and four orthopaedic wards in a university hospital in England. We excluded patients who had just had operations and were confused. We did this survey on wards in which name boards and name cards were still displayed. We also stated that these help medical and nursing staff to locate each patient on the ward. The questionnaires are on bmj.com.

We collected 465 questionnaires, of which seven were excluded because more than one option had been chosen. We included 243 patients and 215 visitors, of whom 181 were from orthopaedic and 277 from surgical wards. Patients' mean age was 62.8 (range $17-94)$, and visitors' mean age was 58.2 (18-85) years. Results of the survey are given in the table. Overall, 233 $(96 \%)$ patients were in favour of having their names written on the name boards, and $194(90 \%)$ of the

\section{What is already known on this topic}

Patients in wards used to be identifiable from name boards at the nurses' station and by names above their bed

The Data Protection Act 1998 throws the legality of this into confusion, but unidentifiable patients may receive substandard care

\section{What this study adds}

Most patients and visitors do not mind being identified

Responses of 243 patients and 215 visitors to questionnaires about patients in hospital having their names displayed. Values are numbers; percentages ( $95 \%$ confidence intervals)

\begin{tabular}{lccc}
\multicolumn{2}{c}{ Patients } & Visitors & Totals \\
\hline \begin{tabular}{llll}
\hline Have you seen the name board or not? & & \\
\hline Yes & $173 ; 71(65$ to 77$)$ & $157 ; 73(67$ to 79$)$ & $330 ; 72$ (68 to 77$)$ \\
\hline No & $70 ; 29(23$ to 35$)$ & $58 ; 27(21$ to 33$)$ & $128 ; 28$ (24 to 32$)$ \\
\hline
\end{tabular}
\end{tabular}

Where should the name board be located?

\begin{tabular}{lccc}
\hline In the open & $182 ; 75(70$ to 80$)$ & $160 ; 74(69$ to 80$)$ & $342 ; 75$ (70 to 79$)$ \\
\hline Hidden & $4 ; 2(-3$ to 7$)$ & $12 ; 6(0$ to 12$)$ & $16 ; 3$ (2 to 5$)$ \\
\hline No preference & $57 ; 23(19$ to 28$)$ & $43 ; 20(14$ to 26$)$ & $100 ; 22$ (18 to 26$)$
\end{tabular}

Do you mind having your name displayed on the name board (or, does this infringe on patients' privacy?)

\begin{tabular}{|c|c|c|c|}
\hline Yes & $10 ; 4$ (2 to 7$)$ & $21 ; 10$ (2 to 5$)$ & $31 ; 7$ (4 to 9$)$ \\
\hline No & $233 ; 96$ (93 to 98$)$ & 194; 90 (84 to 94 ) & $427 ; 93$ (91 to 96$)$ \\
\hline \multicolumn{4}{|c|}{ Should patients' names be displayed above their beds? } \\
\hline Yes & 236; 97 (95 to 99) & 201; 93 (90 to 97 ) & 437; 95 (94 to 97) \\
\hline No & $7 ; 3$ (5 to 8$)$ & $14 ; 7$ (3 to 10$)$ & $21 ; 5$ (3 to 7 ) \\
\hline
\end{tabular}

visitors did not think this infringed upon patients' privacy. When asked about name cards, 236 (97\%) patients and 201 (93\%) visitors were in favour of names being displayed. Sixteen (3\%) were opposed to having name boards placed in the open. Seventy $(29 \%)$ patients and $58(27 \%)$ visitors had not noticed the name boards displayed in the wards.

\section{Comment}

Most patients and visitors do not object to having their names displayed either on cards above their beds or on name boards in front of the nurses' station. A minority of patients prefer not to have their names displayed; displaying only their initials and their consultant's name may anonymise these. Name boards and name cards should be clearly displayed in the ward to ensure the safe delivery of care to patients.

We thank Ian Russell, professor of public health and director of the Institute of Medical and Social Care Research, University of Wales, Bangor, for his help in statistical analysis.

Contributors: LRJ had the idea for the study. All authors prepared the questionnaires and collected data. SL prepared the draft; all other authors modified it. RG is guarantor.

Funding: No additional funding.

Competing interests: None declared.

Ethical approval: This project was registered as an audit project.

Data Protection Act 1998. London: Stationery Office, 1998. www.hmso.gov.uk/acts/acts1998/19980029.htm (accessed 8 Dec 2004).

Information Commissioner's Office. Use and disclosure of health data: guidance on the application of the Data Protection Act 1998. London: ICO, 2002. http://ico-cms.amaze.co.uk/DocumentUploads/use $\% 20$ and $\% 20$ disclosure $\% 20 \mathrm{of} \%$ 20health $\% 20$ data.pdf (accessed 8 Dec 2004).

Department of Surgery, Ysbyty Gwynedd, Bangor LL57 2PW

Ravindra Gudena senior house officer, trauma and orthopaedics

Stanley Luwemba senior house officer, general surgery Amy Williams house officer, general surgery

Lloyd R Jenkinson consultant general surgeon

Correspondence to: R Gudena gudenar@msn.com

BMJ 2004;329:1491

questionnaires are on bmi.com 